\title{
Latitudinal diversity patterns of deep-sea marine nematodes and organic fluxes: a test from the central equatorial Pacific
}

\author{
P. John D. Lambshead ${ }^{1, *}$, Caroline J. Brown ${ }^{1,3}$, Timothy J. Ferrero ${ }^{1}$, Nicola J. Mitchell ${ }^{1}$, \\ Craig R. Smith ${ }^{2}$, Lawrence E. Hawkins ${ }^{3}$, John Tietjen ${ }^{4}$ \\ ${ }^{1}$ Department of Zoology, The Natural History Museum, London SW7 5BD, United Kingdom \\ ${ }^{2}$ Department of Oceanography, University of Hawaii at Mañoa, 1000 Pope Road, Honolulu, Hawaii 96822, USA \\ ${ }^{3}$ School of Ocean and Earth Science, University of Southampton, Southampton Oceanography Centre, Waterfront Campus, \\ European Way, Southampton SO14 3ZH, United Kingdom \\ ${ }^{4}$ Division of Invertebrates, American Museum of Natural History, New York, New York 10024, USA
}

\begin{abstract}
The discovery of an apparently positive latitudinal gradient in nematode species richness over a limited geographic area in the North Atlantic, leading to the hypothesis that it is associated with a positive latitudinal organic flux gradient, has created some debate. A test of this hypothesis is that the negative latitudinal organic flux gradient in the central equatorial Pacific should lead to an associated negative gradient in species richness. Here, we show that species richness in the central equatorial Pacific is positively associated with the organic flux predicted from the pattern reported for the North Atlantic. The patterns in nematode species richness differ from other deep-sea organisms; they seem to be entirely related to modern ecology and unaffected by historical events.
\end{abstract}

KEY WORDS: Pacific $\cdot$ Nematodes $\cdot$ Latitude $\cdot$ Species richness $\cdot$ Diversity $\cdot$ Organic flux $\cdot$ ClarionClipperton fracture zone

\section{INTRODUCTION}

Research into latitudinal gradients has a long history, particularly for terrestrial organisms (see. references in Rosenzweig 1995 and Lambshead et al. 2000). However, investigation of the diversity and species richness of deep-sea Metazoa over latitudinal scales is relatively new and, so far, restricted to molluscs, isopods and, latterly, nematodes (Rex et al. 1993, 1997, 2000, Lambshead et al. 2000). Most deep-sea metazoan data have been collected from the North Atlantic for purposes other than large-scale studies. Interpretation of these data may be problematical as this ocean is divided into separate basins, each of which has the potential for different ecological properties that might

*E-mail: pjdl@nhm.ac.uk obscure any large-scale latitudinal gradient. One basin in particular, the Norwegian Sea, is especially problematical because its recent history differs from that of other North Atlantic basins (see references in Lambshead et al. 2000), and this seems to be reflected in the faunal biodiversity, although the data are limited.

Data for 3 deep-sea North Atlantic macrofaunal taxa showed a decline in ecological diversity from the equator northwards (Rex et al. 1993). Ecological diversity was measured by an index that incorporated both species richness and the relative proportional abundance between species, i.e. equitability (ecological diversity is also called heterogeneity diversity: Peet 1974, Gray 2000). Macrofauna species richness in the deep North Atlantic showed a similar pattern (Rex et al. 2000). Nematode ecological diversity in the deep-sea North Atlantic shows no latitudinal gradient, whereas species richness increases from 13 to $56^{\circ}$ with a distinct drop in 
the Norwegian Sea (Lambshead et al. 2000). These authors suggested that the pattern of nematode species richness was caused by the general trend of increasing surface productivity from the equator. Tietjen (1984) previously reported a positive association between the surface productivity and deep-sea nematode ecological diversity in the North Atlantic.

Ecological diversity indices are sensitive to local ecology because they incorporate a measure of equitability (Gage \& May 1993). This may explain the inability of Lambshead et al. (2000) to detect a latitudinal gradient in the North Atlantic using the rarefaction index, because this ocean consists of a series of basins, each of which may have its own individual ecology. In the surface-productivity-controlled North Atlantic, any latitudinal grdient in species richness may be partially obscured by lateral transport of organic matter from the coasts, as the data are largely drawn from collection sites close to the continents (Lambshead et al. 2000). Rex et al. (2001) re-analysed the nematode data and suggested that the species richness pattern is confounded by depth, although this conclusion was disputed by Lambshead et al. (2001).

Lambshead et al. (2000) identified the equatorial central Pacific as a better location to test for a productivity-related latitudinal gradient in nematode species richness than the North Atlantic. The central equatorial Pacific region has advantages over the North Atlantic for investigating large-scale gradients because it (1) is not divided into ecologically distinct basins, (2) is separated from coastal influences and (3) lacks historical disturbance events such as those that have influenced the Norwegian Sea. In addition, Smith et al. (1997) have shown a strong association between benthic biological and chemical processes and the latitudinal variation in organic flux of this region.

An important advantage in the Pacific data presented here over the North Atlantic data employed by Lambshead et al. (2000) is that the Pacific samples were controlled for depth by collection from the same depth zone. This was the strategy used by Culver \& Buzas (2000) to investigate latitudinal gradients in foraminifers and this strategy was recommended by Rex et al. (2001).

Lambshead et al. (2000) made 3 predictions which would act as a test whether their hypothesis that a latitudinal gradient in nematode species richness in the North Atlantic was partially explained by a latitudinal gradient in organic flux to the sea floor had generality: (1) They predicted that polychaetes would show a positive latitudinal gradient in species richness similar to that of the nematodes, as the distribution of the former also appeared to be coupled to organic flux. This was investigated by Glover et al. (2001) for the NE Atlantic, and their (geographically limited) data set showed a south to north increase in biodiversity consistent with Lambshead et al.'s hypothesis. (2) They predicted that there would be a declining latitudinal gradient in species richness in the central equatorial Pacific from the equator northwards reflecting the decline in organic flux to the sea floor. (3) They predicted that in the central equatorial Pacific, ecological diversity patterns (as indicated by a diversity index) would be similar to species richness (as indicated by a species count) because of the less complex ecological situation in this area. This paper sets out to test Predictions 2 and 3.

\section{MATERIALS AND METHODS}

Study area. The study area is shown in Fig. 1. Sediment samples were collected at 4 'EqPac' sites along a latitudinal gradient of phytodetrital deposition and organic-carbon flux from 0 to $9^{\circ} \mathrm{N}$ at $140^{\circ} \mathrm{W}$ in the central equatorial Pacific as part of the US Joint Global Ocean Flux Study (JGOFS). Smith et al. (1996) reported that stations at 0,2 and $5^{\circ} \mathrm{N}$ on the $140^{\circ} \mathrm{W}$ transect had received a visible input of phytodetritus. The presence of measurable quantities of chlorophyll $a$ and excess ${ }^{234}$ Thorium (tracers with degradation time-scales of less than 100 d; Stephens et al. 1997, Aller \& DeMaster 1984, respectively), phytoplankton with intact chloroplasts, and high respiration rates of associated microbial populations implied that this material was recently settled and undegraded (Smith et al. 1996). In contrast,

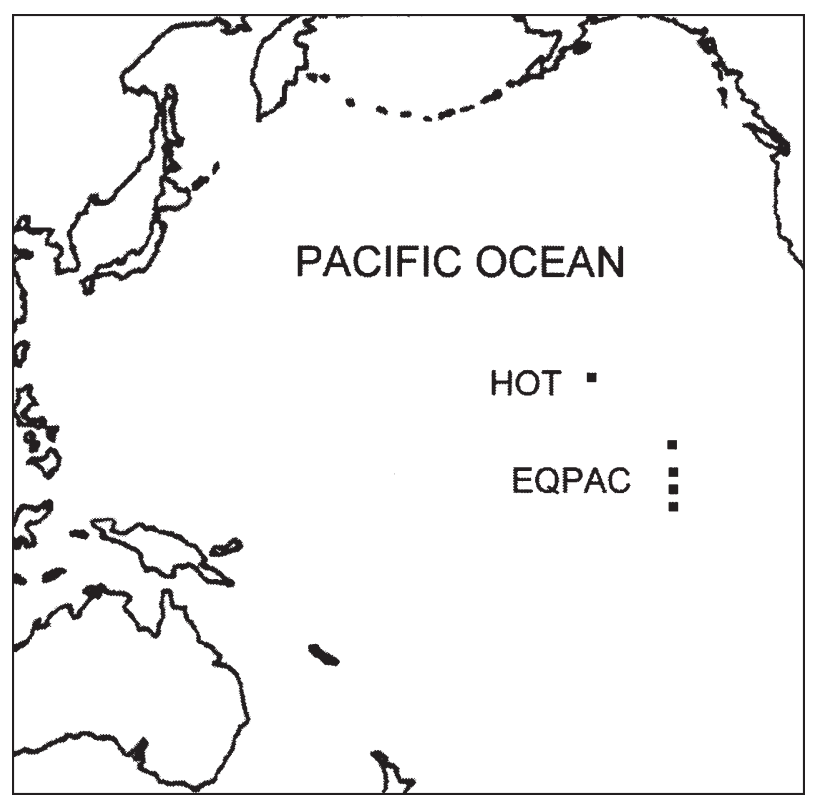

Fig. 1. Map of the central equatorial Pacific showing the 4 'EqPac' (Equatorial Pacific) stations at the equator and $2^{\circ} \mathrm{N}$, $5^{\circ} \mathrm{N}$ and $9^{\circ} \mathrm{N}$, and the Hawaii Ocean Time Series (HOT) station $\left(23^{\circ} \mathrm{N}\right)$ 
at $9^{\circ} \mathrm{N}$, the surface detritus appeared to be much more refractory in nature. Overall, the annual abyssal, particulate organic carbon (POC) flux exhibits a 4-fold increase between $9^{\circ} \mathrm{N}$ and the equator (Dymond \& Collier 1988, Honjo et al. 1995) giving 'large latitudinal gradients in biogenic particle flux to the abyssal seafloor' (Smith et al. 1997).

A site at $23^{\circ} \mathrm{N}, 158^{\circ} \mathrm{W}$, beneath the Hawaii Ocean Time Series (HOT) site (Karl et al. 1996), was also considered a non-phytodetritus site, as only a thin veneer of phytodetrital material was recorded from the seafloor at this site on 1 occasion. The deep carbon flux at $23^{\circ} \mathrm{N}$ was similar to that at the $9^{\circ} \mathrm{N}$ site (Karl et al. 1996).

All 5 stations were located on a predominately flat, sediment-covered abyssal plain. Earlier studies indicated that they were positioned along a gradient of overlying primary productivity, POC flux and sediment accumulation rate (Murray et al. 1992). As far as is known, all other environmental variables were approximately constant. Sampling locations, collection dates and water depths are listed in Table 1, and details are given in Brown et al. (2001).

This study area is in the region of the ClippertonClarion Fracture zone, a part of the deep sea that may be subject to deep-sea mining.

Sampling methods. Samples were obtained using either a multiple-corer similar to that of Barnett et al. (1984) but with $10 \mathrm{~cm}$ diameter tubes, or a USNEL-type box-corer (Hessler \& Jumars 1974) divided in situ into $10 \times 10 \mathrm{~cm}$ subcores (Jumars 1975). Bett et al. (1994) provided evidence that box-cores may recover less of the superficial sediment layer and its associated fauna, depending on various factors including sediment type and the method of deployment, so the multiple-corer is a more efficient collector of meiofauna. However, the results of earlier studies (Brown 1998, Brown et al. 2001) did not suggest sampler bias in these data. In addition, in this study, multiple-corers were primarily employed at the most northern HOT station (Table 1) where nematode biodiversity was predicted to be lowest. The study is therefore conservative with respect to any bias due to the more efficient sampling system employed at HOT, as sampler bias would tend to increase measured biodiversity at this station.

Following sampler recovery, cores were sliced at $1 \mathrm{~cm}$ vertical intervals and transferred to buffered formaldehyde, diluted to $4 \% \mathrm{v} / \mathrm{v}$ with seawater. A single multiple-core tube or box-core subcore was used per deployment. The overlying top water was combined with the 0 to $1 \mathrm{~cm}$ sediment layer. Nematodes were extracted using a modified Ludox ${ }^{\circledR}$ flotation method (Brown 1998) on a $45 \mu \mathrm{m}$ sieve. All nematodes extracted from the sediments were mounted in anhydrous glycerine and are deposited in The Natural His- tory Museum, London. Approximately 100 individuals were selected at random (see Brown et al. 2001) for identification from each sample, so that sample sizes were similar. Individuals were identified to genus level and sorted into morphological species using the pictorial key to world genera developed by Platt \& Warwick (1983), and also the wider taxonomic literature including those referenced in the Bremerhaven Checklist of Aquatic Nematodes (Gerlach \& Riemann 1973, 1974).

The spatial scale at which biodiversity was measured is at the level of the sample. Gray (2000) recommends identifying the biodiversity of a single benthic sample with Whittaker's (1972) point-diversity, but where a number of sampling units are taken within a broader area, as in this study, Gray prefers the term 'sample species richness' which he equates to Whittaker's alpha diversity.

The data were analysed in 2 ways: species richness was estimated by a count of the number of species per core, and ecological diversity by Sanders (1968) rarefaction as modified by Hurlbert (1971). The rarefaction property of being robust to sample size is not necessary for analysis of these data, which utilises similar sample sizes. Rather the index is employed here for compatibility with the North Atlantic and other extant data where a variety of sample sizes have been employed. This index, ES (51) (number of species per 51 individuals per sample), has become a standard technique, although it is not without problems (see Gray 2000, Lambshead et al. 2000).

Samples are treated as independent for the analysis. This strategy incorporates a degree of pseudo-replication because the samples are clustered into stations, but such an approach has been used successfully in detecting latitudinal gradients in deep-sea biodiversity (Rex et al. 1993).

Linear regression was used to determine to what degree ecological diversity and species richness could be explained by latitude. In these data, it was not necessary to control for depth statistically because this had already been achieved by the sampling strategy. Similarly, it was not necessary to control for sample size because this was achieved by the experimental design.

The reduction in flux to the sea floor had a steep gradient between the 5 and $9^{\circ} \mathrm{N}$ stations. The samples could be seen to derive from 2 ecological regions, a high-flux southern region $\left(0\right.$ to $\left.5^{\circ} \mathrm{N}\right)$ and a low-flux northern region $\left(9\right.$ to $\left.23^{\circ} \mathrm{N}\right)$. The prediction then is that the northern region would have a lower ecological diversity and species richness than the southern region. This was analysed using non-parametric MannWhitney $U$-tests. The commercially available 'Minitab' programme was employed for statistical analysis. These types of analyses are only associative: they can disprove hypotheses, but can support hypotheses only 
by yielding results that are consistent with predictions; direct cause and effect is not tested.

\section{RESULTS}

The results of the ecological diversity and species richness analyses are shown in Table 1. It should be noted that where samples were taken by multiple corer and box corer from the same station, there was no evidence for sampler bias. Linear regression of the rarefaction index on latitude (Fig. 2) gave a significant line $(\mathrm{p}<0.001)$ with a negative gradient described by the formula $y=33.4-0.232 x$. Half the variance in the data was predicted by latitude $\left(r^{2}=50.2 \%\right)$. Similarly, linear regression of species richness on latitude (Fig. 3) also gave a significant line $(\mathrm{p}=0.003)$ with a negative gradient described by the formula $y=51.1-0.384 x$. Less of the variance in species richness was predicted by latitude $\left(\mathrm{r}^{2}=38.2 \%\right)$.

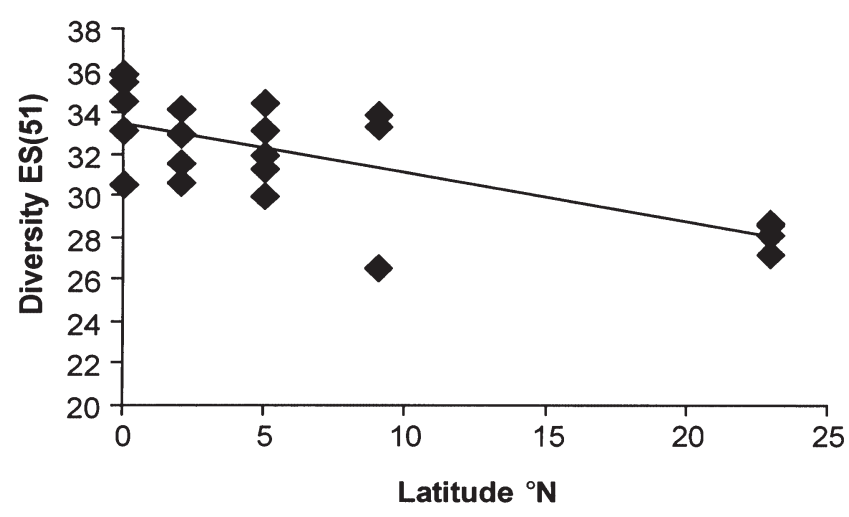

Fig. 2. Ecological diversity of nematodes measured using the rarefaction index ES (51) (number of species per 51 individuals per sample) plotted against latitude in the central equatorial Pacific. Line is a fitted linear regression (see 'Results')

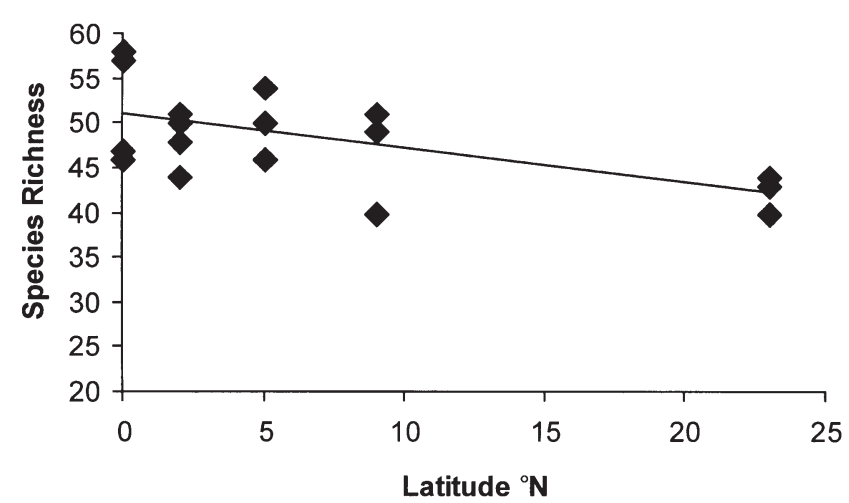

Fig. 3. Species richness of nematodes per sample plotted against latitude in the central equatorial Pacific. Line is a fitted linear regression (see 'Results')
The Mann-Whitney $U$-tests confirmed that the northern region had a significantly lower ecological diversity $(p=0.023)$ than the southern region, although the drop in diversity was small (ES[51] median of 28.60 and 33.09, respectively). In addition, the northern region had a significantly lower species richness than the southern region $(p=0.017)$, although again the difference was quite small (median of 44.00 and 50.00, respectively).

\section{DISCUSSION}

The ecological diversity and species richness patterns for nematodes in the central equatorial Pacific are consistent with the suggestion of Lambshead et al. (2000) that the organic flux to the sea floor partially explains gradients in deep-sea nematode biodiversity over latitudinal scales. The relationship is positive, and so Prediction 2 appears to be supported. It is worth restating that the positive association between deepsea nematode biodiversity and organic flux is entirely based on correlative statistics and limited data. Therefore, although a credible mechanism has been suggested (Lambshead \& Hodda 1994, Rice \& Lambshead 1994) based on patch dynamics, the generality of this pattern requires further testing. Nematodes appear to have a different latitudinal pattern from molluscs, isopods and foraminifers (Rex et al. 1993, 1997, 2000, Culver \& Buzas 2000), but possibly have a pattern similar to that of polychaetes (Glover et al. 2001).

In this study, unlike the Atlantic study of Lambshead et al. (2000), analyses of species richness and ecological diversity showed the same pattern (Prediction 3). This is consistent with the hypothesis that the inability to find a consistent pattern of ecological diversity in the North Atlantic results from its division into basins with non-identical ecological characteristics, unlike the situation in the central Pacific.

There is no reason to assume that the pattern of declining nematode species richness from the equator in the central Pacific extends further than the limited distance studied to the north, with possibly a mirrorimage pattern in the southern hemisphere. Indeed, the distribution of surface productivity in the Pacific would suggest that the pattern reported here is specific to the region studied. This raises the issue of what constitutes a 'latitudinal gradient'; the phrase is defined in this paper simply as a biodiversity pattern that correlates with latitude.

Rohde (1999, see also Rohde 1992) points out that the correlation between productivity and latitudinal gradients may be misleading because the more fundamental correlation is with energy input (whether measured by temperature, evapotranspiration or productivity), and 
energy input could create biodiversity gradients through 'effective evolutionary time', i.e. evolutionary speed coupled with the length of geological time over which a community has existed. It is not immediately clear how to relate this concept to putative deepsea latitudinal gradients, because deep-sea animals in recent history have not been subject to a temperature gradient (excluding the depthrelated temperature gradient). In general, marine organisms are more buffered against temperature variation than land organisms. Whether evolutionary rates are a significant factor in large-scale biodiversity patterns of marine fauna is still a matter of debate (e.g. Flessa \& Jablonski 1996, Crame \& Clarke 1997).

The patterns of benthic biodiversity are different for the northern and southern hemispheres, especially at the poles-the southern ocean is vastly more species-rich than the northern ocean (Clarke \& Crame 1997). Where classic latitudinal gradients are considered to exist in freeliving organisms, they tend to be found in calcareous fauna such as molluscs and foraminifers. Even then, historical events can severely warp putative latitudinal gradients. For example, an analysis of molluscan biodiversity actually shows 2 'hot spots', in the equatorial Indo-West Pacific and the eastern Pacific, with diversity declining away from these points (Clark \& Crame 1997).

Crame (2000) reported that the larger of the 2 tropical high-diversity foci is closely associated with the world's richest development in coral reefs. This author points out that 'the steepest latitudinal gradients are associated with the geologically youngest bivalve clades' which are still spreading from a tropical centre of evolutionary diversification. In other words clade history may be a major determinant in the modern temporal 'snapshot' of the observed latitudinal pattern. The biodiversity pattern for deep-sea molluscs in the North Atlantic reported by Rex et al. $(1993,1997,2000)$ could be viewed as consistent with the general molluscan pattern of declining diversity away from 2 equatorial 'hot spots'.
Table 1. Station location, water depth, collecting date and device, ecological diversity (as the rarefaction index, ES[51]) and species richness per sample

\begin{tabular}{|c|c|c|c|c|c|c|}
\hline $\begin{array}{l}\text { Sample } \\
\text { no. }\end{array}$ & Location & $\begin{array}{c}\text { Water } \\
\text { depth (m) }\end{array}$ & $\begin{array}{l}\text { Collection } \\
\text { date }\end{array}$ & $\begin{array}{l}\text { Collecting } \\
\text { device }\end{array}$ & $\mathrm{ES}(51)$ & $\begin{array}{l}\text { Species } \\
\text { richness }\end{array}$ \\
\hline $\mathrm{BC} 4$ & $\begin{array}{l}00^{\circ} 06.00^{\prime} \mathrm{N} \\
139^{\circ} 43.90^{\prime} \mathrm{W}\end{array}$ & 4328 & 15 Nov 92 & Box-corer & 33.15 & 46 \\
\hline BC6 & $\begin{array}{l}00^{\circ} 06.62^{\prime} \mathrm{N} \\
139^{\circ} 43.96^{\prime} \mathrm{W}\end{array}$ & 4305 & 16 Nov 92 & Box-corer & 35.83 & 57 \\
\hline $\mathrm{BC} 7$ & $\begin{array}{l}00^{\circ} 06.40^{\prime} \mathrm{N} \\
139^{\circ} 44.10^{\prime} \mathrm{W}\end{array}$ & 4307 & 18 Nov 92 & Box-corer & 30.58 & 47 \\
\hline $\mathrm{BC} 8$ & $\begin{array}{l}00^{\circ} 06.98^{\prime} \mathrm{N} \\
139^{\circ} 43.94^{\prime} \mathrm{W}\end{array}$ & 4301 & 19 Nov 92 & Box-corer & 34.61 & 57 \\
\hline MC15 & $\begin{array}{l}00^{\circ} 06.57^{\prime} \mathrm{N} \\
139^{\circ} 43.42^{\prime} \mathrm{W}\end{array}$ & 4304 & 19 Nov 92 & Multiple-corer & 35.53 & 58 \\
\hline BC9 & $\begin{array}{l}02^{\circ} 03.94^{\prime} \mathrm{N} \\
140^{\circ} 08.94^{\prime} \mathrm{W}\end{array}$ & 4409 & 20 Nov 92 & Box-corer & 31.61 & 48 \\
\hline $\mathrm{BC} 10$ & $\begin{array}{l}02^{\circ} 04.00^{\prime} \mathrm{N} \\
140^{\circ} 07.90^{\prime} \mathrm{W}\end{array}$ & 4414 & 21 Nov 92 & Box-corer & 30.66 & 44 \\
\hline BC11 & $\begin{array}{l}02^{\circ} 03.96^{\prime} \mathrm{N} \\
140^{\circ} 08.06^{\prime} \mathrm{W}\end{array}$ & 4409 & 22 Nov 92 & Box-corer & 34.24 & 51 \\
\hline BC12 & $\begin{array}{l}02^{\circ} 03.80^{\prime} \mathrm{N} \\
140^{\circ} 07.90^{\prime} \mathrm{W}\end{array}$ & 4410 & 23 Nov 92 & Box-corer & 33.03 & 50 \\
\hline BC15 & $\begin{array}{l}05^{\circ} 05.00^{\prime} \mathrm{N} \\
139^{\circ} 39.00^{\prime} \mathrm{W}\end{array}$ & 4447 & 27 Nov 92 & Box-corer & 30.04 & 46 \\
\hline BC16 & $\begin{array}{l}05^{\circ} 04.42^{\prime} \mathrm{N} \\
139^{\circ} 38.90^{\prime} \mathrm{W}\end{array}$ & 4446 & 28 Nov 92 & Box-corer & 31.94 & 46 \\
\hline BC17 & $\begin{array}{l}05^{\circ} 04.80^{\prime} \mathrm{N} \\
139^{\circ} 38.50^{\prime} \mathrm{W}\end{array}$ & 4424 & 29 Nov 92 & Box-corer & 34.46 & 54 \\
\hline BC18 & $\begin{array}{l}05^{\circ} 04.20^{\prime} \mathrm{N} \\
139^{\circ} 38.40^{\prime} \mathrm{W}\end{array}$ & 4320 & 30 Nov 92 & Box-corer & 33.16 & 50 \\
\hline MC26 & $\begin{array}{l}05^{\circ} 04.30^{\prime} \mathrm{N} \\
139^{\circ} 38.30^{\prime} \mathrm{W}\end{array}$ & 4418 & 30 Nov 92 & Multiple-corer & 31.28 & 50 \\
\hline BC19 & $\begin{array}{l}08^{\circ} 55.08^{\prime} \mathrm{N} \\
139^{\circ} 52.20^{\prime} \mathrm{W}\end{array}$ & 4986 & 3 Dec 92 & Box-corer & 33.34 & 51 \\
\hline $\mathrm{BC} 20$ & $\begin{array}{l}08^{\circ} 56.04^{\prime} \mathrm{N}, \\
139^{\circ} 51.55^{\prime} \mathrm{W}\end{array}$ & 4994 & 4 Dec 92 & Box-corer & 26.58 & 40 \\
\hline BC22 & $\begin{array}{l}08^{\circ} 55.80^{\prime} \mathrm{N} \\
139^{\circ} 52.30^{\prime} \mathrm{W}\end{array}$ & 4991 & 6 Dec 92 & Box-corer & 33.90 & 49 \\
\hline MC1 & $\begin{array}{l}22^{\circ} 54.69^{\prime} \mathrm{N} \\
157^{\circ} 49.74^{\prime} \mathrm{W}\end{array}$ & 4880 & 29 Jul 92 & Multiple-corer & 28.60 & 44 \\
\hline $\mathrm{MC} 2$ & $\begin{array}{l}22^{\circ} 54.95^{\prime} \mathrm{N} \\
157^{\circ} 49.93^{\prime} \mathrm{W}\end{array}$ & 4871 & 29 Jul 92 & Multiple-corer & 28.16 & 43 \\
\hline $\mathrm{MC} 4$ & $\begin{array}{l}22^{\circ} 54.74^{\prime} \mathrm{N} \\
157^{\circ} 50.21^{\prime} \mathrm{W}\end{array}$ & 4880 & 31 Jul 92 & Multiple-corer & 27.26 & 40 \\
\hline MC6 & $\begin{array}{l}22^{\circ} 54.64^{\prime} \mathrm{N} \\
157^{\circ} 49.86^{\prime} \mathrm{W}\end{array}$ & 4884 & 1 Aug 92 & Multiple-corer & 28.72 & 44 \\
\hline
\end{tabular}

Foraminifers show a similar pattern to molluscs in the North Atlantic, but not in the South Atlantic, where there is also a declining biodiversity at higher latitudes, although in general foraminiferal diversity is higher in the South Atlantic (Culver \& Buzas 2000). However, the processes causing the foraminiferal North Atlantic pattern seem to differ from the processes causing the molluscan pattern. Seasonality of 
food supply at higher latitudes since the early Oligocene is associated with low foraminiferal diversity (Thomas \& Gooday 1996).

Whether the above evidence is perceived as evidence for or against classical latitudinal gradients in the marine environment is debatable. Clarke \& Crame (1997) after commenting on problems with the literature data concluded: 'Nevertheless we are left with the result that no study of shallow-water soft-bottom infauna communities has yet provided convincing evidence of a latitudinal cline in alpha diversity.' These authors observed that 'several taxa are known to be diverse in the Southern Ocean (for example polychaetes, bryozoans, ascidians, sponges, amphipods and isopods) and the pattern of a cline in diversity with latitude may not be a general one.'

The limited data available suggest that deep-sea organisms show a variety of biodiversity patterns because of their different natural histories interacting with both modern and historical ecological conditions. For example, Eckelbarger \& Watling (1995) made the point that different taxa have different reproductive responses to deep-sea phytodetritus inputs, depending on phylogenetic constraints on their biology.

Two characteristics make nematodes different from other taxa, their relatively low ability to disperse (Lambshead 1993) and their resistance to low oxygen conditions (Cook et al. 2000, Rogers 2000, Wetzel et al. 2001). This may give a pattern of 'speciation in place' in the deep sea from survivors of the large-scale dysoxic event in the Palaeocene to early Eocene (Jacobs \& Lindberg 1998) rather than a pattern of postevent migration into the deep sea found in a variety of larger organisms, e.g the isopod superfamily Janiroidea (Hessler \& Thistle 1975, Wilson 1998), the amphipod species complex Eurythenes gryllus (France \& Kocher 1996), elasipodid holothurians (Gebruk 1994), and nuculanid bivalves (Madsen 1961). As a group, molluscs show a pattern of migration from a speciation centre (Crame 2000). Nematode diversities at the Pacific stations analysed here are similar to those reported previously for Atlantic abyssal stations (Lambshead et al. 2000). There is no evidence for a similar pattern in the molluscs. The limited evidence is more suggestive of a pattern of speciation in place, until equilibrium of regional speciation and extinction is reached, depending on regional ecological conditions.

The general hypothesis from the North Atlantic (Lambshead et al. 2000) and Pacific studies is that species richness of deep-sea nematodes will tend to correlate positively with food availability rather than historical phenomena (although there are exceptions such as the Norwegian Sea: Lambshead et al. 2000). Ecological diversity may show the same pattern, but is more sensitive to local ecological factors. The evidence from deep-sea studies suggests that there is no reason to expect that all faunas will show similar latitudinal patterns or even necessarily the same pattern from ocean to ocean. Historical and geographical processes may be taxon- and location-specific, and even ecological processes may be taxon-specific.

Acknowledgements. The support provided by a Fulbright bursary and a joint NHM-University of Southampton studentship to one of the authors (C.J.B.) is gratefully acknowledged. The work was also part funded by US NSF grant no. OCE 90-22116 to C. R. S. This is contribution no. 5981 from SOEST, and no. 766 from the US JGOFS programme. Thanks are also due to N. Mitchell, P. Rainbow, M. Rex, A. Rogers and D. Thistle for critically reading the manuscript.

\section{LITERATURE CITED}

Aller RC, DeMaster DJ (1984) Estimates of particle flux and reworking at the deep-sea floor using Th-234/U-238 disequilibrium. Earth Planet Sci Lett 67:308-318

Barnett PRO, Watson J, Connolly D (1984) A multiple corer for taking virtually undisturbed samples from shelf, bathyal and abyssal sediments. Oceanol Acta 7:399-408

Bett BJ, Vanreusel A, Vincx M, Soltwedel T and 5 others (1994) Sampler bias in the quantitative study of deep sea meiobenthos. Mar Ecol Prog Ser 104:197-203

Brown CJ (1998) Effects of a phytodetrital input on nematode communities of the abyssal, equatorial Pacific. PhD thesis, University of Southampton

Brown CJ, Lambshead PJD, Smith CR, Hawkins LE, Farley R (2001) Phytodetritus and the abundance and biomass of abyssal nematodes in the central, equatorial Pacific. DeepSea Res Part I 48:555-565

Clarke A, Crame JA (1997) Diversity, latitude and time: patterns in the shallow sea. In: Ormond RFG, Gage JD, Angel MV (eds) Marine biodiversity. Cambridge University Press, Cambridge, p 122-147

Cook AA, Lambshead PJD, Hawkins LE, Mitchell N, Levin LA (2000) Nematode abundance at the oxygen minimum zone in the Arabian Sea. Deep-Sea Res Part II 47:75-85

Crame JA (2000) Evolution of taxonomic diversity gradients in the marine realm: evidence from the composition of recent bivalve faunas. Paleobiology 26:188-214

Crame JA, Clarke A (1997) The historical component of marine taxonomic diversity gradients. In: Ormond RFG, Gage JD, Angel MV (eds) Marine biodiversity. Cambridge University Press, Cambridge, p 258-273

Culver SJ, Buzas MA (2000) Global latitudinal species diversity gradient in deep-sea benthic foraminifera. Deep-Sea Res 47:259-275

Dymond J, Collier R (1988) Biogenic particle fluxes in the equatorial Pacific: evidence for both high and low productivity during the 1982-1983 El Niño. Glob Biogeochem Cycles 2:129-137

Eckelbargar KJ, Watling L (1995) Role of phylogenetic constraints in determining reproductive patterns in deep-sea invertebrates. Invertebr Biol 114:256-269

Flessa KW, Jablonski D (1996) The geography of evolutionary turnover: a global analysis of extant bivalves. In: Jablonski D, Erwin DH, Lipps J (eds) Evolutionary paleobiology. University of Chicago Press, Chicago, p 176-397

France SC, Kocher TD (1996) Geographic and bathymetric patterns of mitochondrial 16S rRNA sequence divergence 
among deep-sea amphipods, Eurythenes gryllus. Mar Biol 126:633-643

Gage JD, May RM (1993) A dip into the deep seas. Nature 365:609-610

Gebruk AV (1994) Two main stages in the evolution of the deep-sea fauna of elsipodid holothurians. In: David B, Guille A, Feral JP, Roux M (eds) Echinoderms through time. Balkema, Rotterdam, p 507-514

Gerlach SA, Riemann F (1973) The Bremerhaven checklist of aquatic nematodes, Vol 1. Veröff Inst Meeresforsch Bremerhav (Suppl) 4:1-404

Gerlach SA, Riemann F (1974) The Bremerhaven checklist of aquatic nematodes, Vol 2. Veröff Inst Meeresforsch Bremerhav (Suppl) 4:405-734

Glover A, Paterson G, Bett B, Gage J, Sibuet M, Sheader M, Hawkins L (2001) Patterns in polychaete abundance and diversity from the Madeira Abyssal Plain, northeast Atlantic. Deep-Sea Res Part I 48:217-236

Gray JS (2000) The measurement of marine species diversity, with an application to the benthic fauna of the Norwegian continental shelf. J Exp Biol Ecol 250:23-49

Hessler RR, Jumars PA (1974) Abyssal community analysis from replicate box cores in the central north Pacific. DeepSea Res 21:185-209

Hessler RR, Thistle D (1975) On the place of origin of deepsea isopods. Mar Biol 32:155-165

Honjo S, Dymond J, Collier R, Manganini SJ (1995) Export production of particles to the interior of the equatorial Pacific Ocean during the 1992 EqPac experiment. DeepSea Res 42:831-870

Hurlbert SH (1971) The non-concept of species diversity: a critique and alternative parameters. Ecology 52:577-586

Jacobs DK, Lindberg DR (1998) Oxygen and evolutionary patterns in the sea; onshore/offshore trends and recent recruitment of deep-sea faunas. Proc Natl Acad Sci USA 95:9396-9401

Jumars PA (1975) Environmental grain and polychaete species diversity in a bathyal benthic community. Mar Biol 30: 253-266

Karl D, Christian J, Dore J, Hebel D, Letelier R, Tupas L, Winn C (1996) Seasonal and interannual variability in primary production and particle flux at Station Aloha. Deep-Sea Res Part II 43:539-568

Lambshead PJD (1993) Recent developments in marine benthic biodiversity research. Oceanis 19:5-24

Lambshead PJD, Hodda M (1994) The impact of disturbance on measurements of variability in marine nematode populations. Vie Milieu 44:21-27

Lambshead PJD, Tietjen J, Ferrero T, Jensen P (2000) Latitudinal diversity gradients in the deep sea with special reference to North Atlantic nematodes. Mar Ecol Prog Ser 194:159-167

Lambshead PJD, Tietjen J, Moncrieff CB, Ferrero T (2001) North Atlantic latitudinal diversity patterns in deep-sea marine nematode data: a reply to Rex et al. Mar Ecol Prog Ser 210:299-301

Madsen FJ (1961) On the zoogeography and origin of the abyssal fauna in view of the knowledge of the Porcellanasteridae. Galathea Report 4:177-218

Murray JW, Leinen MW, Feely RA, Toggweiler JR, Wanninkhof R (1992) EQPAC: a process study in the central equatorial Pacific. Oceanography 5:134-142

Peet RK (1974) The measurement of species diversity. Annu Rev Ecol Syst 5:3285-3307

Platt HM, Warwick RM (1983) Free living marine nematodes.
Part I. British enoplids. Cambridge University Press, Cambridge

Rex MA, Stuart CT, Hessler RR, Allen JA, Sanders HL, Wilson GDF (1993) Global scale latitudinal patterns of species diversity in the deep-sea benthos. Nature 365:636-639

Rex MA, Etter RJ, Stuart CT (1997) Large-scale patterns of species diversity in the deep-sea benthos. In: Ormond RFG, Gage JD, Angel MV (eds) Marine biodiversity. Cambridge University Press, Cambridge, p 94-121

Rex MA, Stuart CT, Coyne G (2000) Latitudinal gradients of species richness in the deep-sea benthos of the North Atlantic. P Natl Acad Sci USA 97:4082-4085

Rex MA, Stuart CT, Etter RJ (2001) A comment on whether deep-sea nematodes show a positive latitudinal gradient of species diversity: the potential role of depth. Mar Ecol Prog Ser 210:297-298

Rice AL, Lambshead PJD (1994) Patch dynamic in deep-sea benthos: the role of a heterogenous supply of organic matter. In: Giller PS, Hildrew AG, Raffaelli DG (eds) Aquatic ecology: scale, pattern and procen. 34th Symposium of the British Ecological Society. Blackwell Scientific Publications, Oxford, p 469-499

Rogers AD (2000) The role of the oceanic oxygen minima in generating biodiversity in the deep sea. Deep-Sea Res Part II 47:119-148

Rohde K (1992) Latitudinal gradients in species diversity: the search for a primary cause. Oikos 65:514-527

Rohde K (1999) Latitudinal gradients in species diversity and Rapoport's rule revisited: a review of recent work and what can parasites teach us about the causes of the gradients? Ecography 22:593-613

Rosenzweig ML (1995) Species diversity in space and time. Cambridge University Press, Cambridge

Sanders HL (1968) Marine benthic diversity: a comparative study. Am Nat 102:243-282

Smith CR, Hoover DJ, Doan SE, Pope RH, Demaster DJ, Dobbs FC, Altabet MC (1996) Phytodetritus at the abyssal seafloor across $10^{\circ}$ of latitude at the central equatorial Pacific. Deep-Sea Res Part II 43:1309-1338

Smith CR, Berelson W, Demaster DJ, Dobbs FC, Hammond D, Hoover DJ, Pope RH, Stephens M (1997) Latitudinal variations in benthic processes in the abyssal equatorial Pacific: control by biogenic particle flux. Deep-Sea Res Part II 44:2295-2317

Stephens MP, Kadko DC, Smith CR, Latasa M (1997) Chlorophyll $a$ and phaeopigments as tracers of labile organic carbon at the central equatorial Pacific seafloor. Geochim Cosmochim Acta 61:4605-4619

Tietjen JH (1984) Distribution and species diversity of deepsea nematodes in the Venezuela Basin. Deep-Sea Res 31: $119-132$

Thomas AE, Gooday AJ (1996) Cenozoic deep-sea benthic foraminifers: tracers for changes in ocean productivity? Geology 24(4):355-358

Wetzel MA, Fleeger JW, Powers SP (2001) Effects of hypoxia and anoxia on meiofauna: a review with new data from the Gulf of Mexico. In: Rabalais NN, Turner RE (eds) Coastal hypoxia: consequences for living resources and ecosystems. Coastal and Estuarine Studies No. 58, American Geophysical Union, Washington, DC

Whittaker RH (1972) Evolution and measurement of species diversity. Taxon 21:213-251

Wilson GDF (1998) Historical influences on deep-sea isopod diversity in the Atlantic Ocean. Deep-Sea Res Part II 45: $279-301$

Submitted: November 1, 2001; Accepted: January 11, 2002 Proofs received from author(s): June 4, 2002 